\title{
UvaMate: A Serious Game for Learning Mathematics for Children with ADHD: Usability Evaluation
}

\author{
"UvaMate", un juego serio para el aprendizaje de matemáticas \\ para niños con TDAH: Evaluación de usabilidad
}

\author{
Claudia Blanca González Calleros ${ }^{1}$ (D), Josefina Guerrero-García² (D) \\ and Yadira Navarro-Rangel ${ }^{1}$ iD
}

${ }^{1}$ Faculty of Electronics Sciences, Benemérita Universidad Autónoma de Puebla (BUAP), Puebla, Mexico.

${ }^{2}$ Faculty of Computer Sciences, Benemérita Universidad Autónoma de Puebla (BUAP), Puebla, Mexico.

claudia.gonzalezcalleros@viep.com.mx,joseguga01@gmail.com, yadiranavarro44@gmail.com

(Received: November 16, 2019; accepted: January 30, 2020)

\begin{abstract}
Even though games that focus on the development of logical-mathematical skills aimed at maintaining the attention of children with ADHD currently exist, there are no applications available to learn how to solve mathematical problems. In view of this problem, a serious game was designed and developed to enable children to achieve significant learning in this subject. An evaluation was performed of the interface of a section of the game focusing on the concept of counting. Work was performed with 7 teachers by means of a Wizard of Oz experiment. A CSUQ questionnaire was also used to gather general information on the teachers, such as gender and age. The children's experience in using the application was also assessed. The study indicates that the current interface is usable, though it requires certain improvements in terms of typography, image design, and color.
\end{abstract}

Keywords: Usability evaluation, Serious games, ADHD, Wizard of Oz, User experience.

Resumen. En la actualidad, si bien existen juegos enfocados al desarrollo de habilidades lógicomatemáticas dirigidos a lograr la atención de niños con TDAH, no hay aplicaciones para el aprendizaje en la resolución de problemas matemáticos. Alineado a esta problemática, se llevó a cabo el diseño y desarrollo de un juego serio que permita que los niños alcancen un aprendizaje significativo en este tema. Se realizó la evaluación de la interfaz de una sección del juego enfocada al concepto de conteo, se trabajó con 7 docentes mediante un experimento de Mago de Oz. Sumado a lo anterior, se aplicó un cuestionario de CSUQ, se recolectaron datos generales de los docentes como sexo y edad. Por otra parte, se valoró la experiencia de los niños durante el uso de la aplicación. El estudio indica que la interfaz actual es utilizable; sin embargo, necesita algunas mejoras en cuanto a tipografía, diseño de imagen y color.

Palabras clave: Evaluación de usabilidad, Juegos serios, TDAH, Mago de Oz, Experiencia de usuario. 


\section{Introduction}

Attention Deficit Hyperactivity Disorder (ADHD) is the most common label for children who display significant problems of attention, impulsiveness and hyperactivity. This disorder affects a significantly heterogeneous population and is one of the main reasons for referring children to doctors and mental health professionals, due to behavioral problems (Barkley \& Murphy, 2006).

ADHD is one of the most prevalent child disorders (American Psychiatric Association, 2000). Based on an extensive literature review, Rief (2012) indicates that between 3 and 5 percent of school-age children have ADHD. In Mexico, approximately 1 in 22 children may be diagnosed with this disorder (PalaciosCruz et al., 2011).

Artigas-Pallarés \& Narbona García (2011) point out that ADHD is characterized by failure or alteration in the development of the functions associated with maturing of the central nervous system; the children display lack of attention, hyperactivity and impulsiveness, which may produce conflicts in the emotional, cognitive, academic and social areas (Alvárez Menéndez \& Pinel González, 2015).

Children and adolescents with ADHD do much better when they are given interesting, innovative and motivating activities. In general, most students with ADHD can learn adequately in a regular classroom when the teachers use effective instruction strategies. Rief (2012) highlights that good teaching practices are useful for all students in the classroom, and that they are at the same time necessary techniques and strategies for the academic success of children with ADHD.

Many resources are available for treatment and learning improvement for children with ADHD. Research by Wouters, van Nimwegen, van Oostendorp, \& van der Spek (2013) indicates that the inclusion of gaming and serious games can promote learning by optimizing the concentration level of the children that use them, which improves learning and offers motivation that is equal to or better than other methods in terms of acquiring knowledge.

Considering the efforts made to incorporate technology in education, there has been motivation to develop tools supported by gaming and serious game techniques in the Mexican context, focusing on teaching mathematics to children with ADHD.

This article is part of a doctoral research project to develop a Model of Instruction Design (MID) for children with ADHD to learn to solve mathematical problems. The objective of this article is to present the results obtained from the usability evaluation of a serious game named "UVAMATE", designed to develop mathematical problem-solving skills in children with ADHD.

The article is grouped into five sections. The second section describes a systematic literature review, including on problems associated with teaching mathematics to children with ADHD, as well as the use of serious games to teach mathematics to children with ADHD. Section three focuses on a methodology to evaluate the proposed game, and the results of the evaluation are presented in section four. Lastly, the fifth section provides a brief summary, a discussion of the results, and future work.

\section{Systematic literature review}

A systematized search was performed based on a heuristic and hermeneutical 9-step process found in the literature (Londoño Palacio, Maldonado Granados, \& Calderón Villafáñez, 2014). A search was made for articles and documents related to the process of teaching-learning mathematics in children with ADHD, as well as the use of serious games as a technological tool to teach mathematics to this vulnerable segment of the population. To this end, a search string was developed identifying the concepts and constructs related to these topics.

It was decided to use articles published within the last 15 years, written in English or Spanish, and that are reported to have been developed for different contexts.

The following criteria were defined for the search: Learning problems of children with ADHD, mathematics learning problems of children with ADHD, use of serious games as a technological tool to promote learning for these children, as well as the use of serious games to promote learning to solve mathematical problems.

Articles were obtained from specialized databases and repositories such as: IEEE, ACM, Springer, Google Schoolar, Sage Journals, EBSCO, among others. A table was prepared to review the searched articles, indicating their characteristics, with the intention of finding differences and similarities between them. In the end, 26 articles were obtained from the databases and repositories. Following an analysis, 15 articles were found to fulfill the defined characteristics and conditions of the search.

An analysis and theoretical construct were developed based on the articles, providing a critical perspective and identifying areas of opportunity for this study. 


\subsection{Problems associated with the teaching-learning process of children with ADHD}

Studies were found in the literature regarding the teaching-learning problems of children with ADHD (Miranda, Jarque, \& Tarraga, 2006). Even though they have normal intelligence, children with this disorder may have attention-span problems, as well as low academic performance and learning problems (Stephen, 2005). Most children with ADHD have school-related problems, and at the same time a high percentage of them have learning disabilities (Rief, 2012).

In addition to the main problems, such as lack of attention, impulsiveness and hyperactivity, children with ADHD may experience problems in the cognitive, developmental and academic areas, and even health-related problems (Rief, 2012).

Miranda et al. (2006) point out that the short attention span of school-age children sometimes affects their performance and behavior in the classroom, because their impulsiveness often implies not following family, interpersonal and/or educational rules.

Fernández Martín, Hinojo Lucena, \& Aznar Díaz (2003) and Rief (2012) have found that learning difficulties and ADHD are interrelated by about 12 and 60 percent, and believe that somewhere between one-third and one-half of children with ADHD have learning disabilities.

The lack of attention makes it difficult to perform processes such as calculations, oral expression, reading and writing, which often require extra assistance and direction from the teachers in charge of developing learning abilities for this segment of the population (Klimenko, 2009).

The literature reports that the teachers' attitudes towards ADHD are far from ideal, and that they are not sufficiently knowledgeable. They label them as spoiled, disobedient, or aggressive children (Nur \& Kavakci, 2010). At the same time, the difficulties faced by teachers who try to teach a child with ADHD at the same time as 25 other children are certainly challenging (Wallace, 2005).

\subsection{Problems associated with teaching-learning mathematics for children with ADHD}

ADHD involves a deficit in self-control, also known as executive functions, which are essential for planning, organizing and carrying out complex activities over long time periods. In children with ADHD, the executive part of the brain, which is in charge or organizing and controlling behavior, does not function effectively (Barkley \& Murphy, 2006).

When there are learning disorders, ADHD or simple ADD may cause low performance in mathematics, largely as a result of aspects related to memory and reading, which affect understanding and elimination of extraneous information when performing multiple operations, or in transforming the information in the mathematical problems (Geary, 2004).

Many students with ADHD have academic difficulties with mathematics because of the many processes and brain functions involved in working on mathematical problems (Rief, 2012).

As mentioned earlier, students with ADHD have attention, memory, and control difficulties, which puts them at a disadvantage in terms of academic performance. The learning difficulties associated with ADHD affect mathematics learning in different ways and at different levels (Miranda Casas, Soriano Ferrer, \& García Castellar, 2002).

In order to solve mathematical problems, the child must follow a series of steps involving different processes. The selection and adequate use of the operations involves resources such as attention, working memory and planning and organization skills. It is therefore no surprise that children with ADHD often try to solve problems without having read carefully, and even when they have read, they are unable to remember the question, and therefore confuse the information or fail to find the difference between the general information of the problem, the unknown information and the information that must be found (Miranda Casas et al., 2002).

According to Rief (2012), the following problems are associated with ADHD: low memory, short attention span, problems in following sequences, low spatial organization, low motor and fine motor skills, difficulties in understanding what they are told, self-management, and self-control problems. All these have a negative effect on performance in mathematics. 


\subsection{Serious games for teaching children with ADHD}

Technology has been used to improve teaching quality in many ways. One of the main ways is to improve the interaction between the teacher and the students. In the literature review, studies were found on the use of serious games and gaming techniques to support learning for children with ADHD.

The use of serious games promotes the development of complex thought skills related to problemsolving (Keller, 1992), logical thought (Higgins, 2000; Whitebread, 1997)), strategy planning (Jenkins, 2002; McFarlane, Sparrowhawk, \& Heald, 2002), as well as self-paced learning (Rieber, 1996; Zimmerman $\&$ Schunk, 2001).

The study by Bul et al. (2015) demonstrates the effectiveness of serious games as a strategy for teaching children with ADHD. It also states that the elements contained in serious games enable them to better direct their activities and to regulate their emotions. Echeverry Chaves \& González Valencia (2014) indicate that serious games are positive for personal development and inclusion in society, as well as a didactic form of entertainment to expose children to the use of modern technologies. On their part, Lau, Smit, Fleming, \& Riper (2017) point out that serious games can be effective in reducing the symptoms related to the disorder.

\subsection{Serious games for teaching mathematics to children with ADHD}

A study by Ford, Poe, \& Cox (1993) compares the effects of the use of two mathematics software packages, and two other packages for reading, aimed at holding the attention of children with ADHD. The study was carried out with diagnosed children in third and fourth grade. The objective of the study was to determine whether the software could increase these children's attention. The results indicate that attention increases when a game format is used without excessive animation. However, this study did not evaluate whether learning was achieved.

Muñoz, Navarro, \& Fabregat (2014) discuss a video game supported by Augmented Reality (AR) to learn logical-mathematical skills. They show that performance in the game is similar for children with special needs, which helps integrate them in the learning process. On their part, Mahmoudi, Koushafar, Saribagloo, \& Pashavi (2015) found that computer games had a significant effect on increasing speed and attention in mathematical calculations. However, the effect of the computer games on mathematical learning and the stability of learning was not significant, which suggests that computer games may be used as a training aid as long as reinforcement is provided by the teachers.

Following this systematic review, we corroborated through interviews and observation of teachers and students diagnosed with ADHD during classroom sessions, that teachers are not knowledgeable about exactly how to work with and assist in improving learning for children with this disorder. Teachers find it difficult to work with a child, especially when they are responsible for groups of over 35 children. Additionally, within the same classroom there are children with other types of disorders or learning problems, and even children with intellectual disability. However, the teachers indicate that they are willing to help and work with them to achieve better learning and bring them up to par with their peers.

Regarding the design of serious games focused on learning mathematics for children with ADHD, even though the literature mentions work done in this area, not all of them have been tested, and in some cases, they indicate that there is no significant difference in learning. Also, most of these games focus on calculating logical-mathematical operations. For this reason, it is of interest to design games based on the special needs of these children, focusing on solving mathematical problems.

In the next section we discuss the proposal of a serious game, as well as a description of the experiment performed for its evaluation.

\section{Methodology}

This section briefly describes the application that was developed, as well as the tasks that can be performed and that will be evaluated.

\subsection{Description of the product to be evaluated}

A serious game is being developed for significant learning on solving mathematical problems for children with ADHD. Work on the "UvaMate" game, illustrated in Figure 1, has been done with 13 children between 
the ages of 8 and 12, diagnosed with ADHD, and 6 teachers who are responsible for the group they belong to. The children are enrolled in a public school in the south side of the city of Puebla, Mexico. The work has consisted of semi-structured interviews with parents, group teachers, and specialists in diagnosing and treating this disorder. At the same time, observations of classroom sessions have been performed to assess the way in which the children learn and the strategies used by teachers in the classroom.

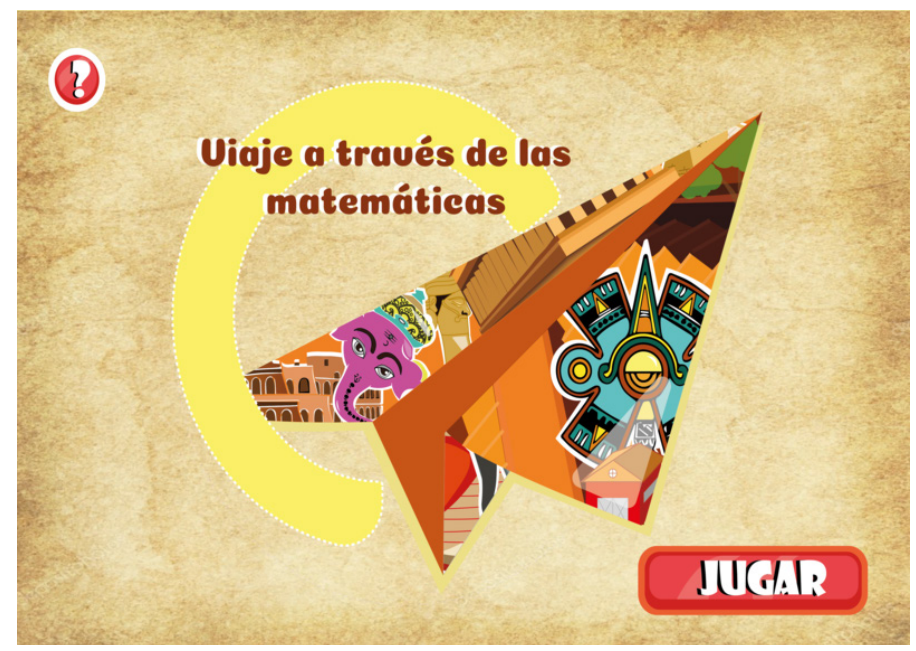

Figure 1. Presentation of the "UvaMate" serious game

"UvaMate" is a game designed to reinforce learning on how to resolve mathematical problems, based on a narrative on the importance of mathematics over a time line of different civilizations, and how mathematics was used to resolve everyday situations. The main character is Pythagoras, who highlights the time line of the different civilizations.

The game includes 9 civilizations, and it is expected that in each of these the child will acquire or reinforce existing knowledge. The problems shown are everyday life problems for each of the eras. The problems included in the game are aligned with the theme contents of the Public Education Secretary. The graphic design elements related to the scenery, characters and costume are aligned with each era.

The civilizations included in the game and the knowledge expected to be learned in each are listed in Table 1.

Table 1. Civilizations of the "UvaMate" game

\begin{tabular}{c|l} 
Civilization & \multicolumn{1}{c}{ Learning } \\
\hline Prehistory & Counting of fruits collected and animals hunted \\
\hline Sumer & $\begin{array}{l}\text { Numbering } \\
\text { Place value } \\
\text { Sexagesimal numbering }\end{array}$ \\
\hline \multirow{2}{*}{ Egypt } & $\begin{array}{l}\text { Basic addition and subtraction operations } \\
\text { Measuring crop lands } \\
\text { Count harvest output } \\
\text { Tax-related pro }\end{array}$ \\
\hline Greece & $\begin{array}{l}\text { Solve distance problems using the Pythagoras theorem } \\
\text { Magical Triangle }\end{array}$ \\
\hline Etruscans & Roman numbering system \\
\hline Rome & Calculating areas and perimeters \\
\hline China & Calculating lengths \\
\hline India & $\begin{array}{l}\text { Multiplication } \\
\text { Galley multiplication }\end{array}$ \\
\hline \multirow{2}{*}{ Mayans } & Mayan numbers \\
& Days, months and years \\
& The calendar \\
\hline
\end{tabular}




\subsection{Experiment Configuration}

In this experiment in particular, work was done with the first civilization, the prehistoric era, to address the concept of counting. The experiment was carried out using the "Wizard of Oz Experiment" technique, which involves a participant who is called the "Wizard", who simulates the role performed by the computer during a human-computer interaction (Fraser \& Gilbert, 1991). The Wizard of Oz simulation method is widely used and is a practical tool to test system prototypes (Dow et al., 2005).

Fraser \& Gilbert (1991) report three stages in this experiment's methodology: the pre-experimental stage, the primary experimental stage and the subsequent experimental stage, which are described in Table 2.

Table 2. Wizard of Oz Experiment methodology

\begin{tabular}{l|l}
\multicolumn{1}{c|}{ Experiment stage } & \multicolumn{1}{c}{ Description } \\
\hline Pre-experimental Stage & $\begin{array}{l}\text { In this stage, an analysis is made of the } \\
\text { application's domain, the possible scenarios (the } \\
\text { subject's role and background), the location } \\
\text { and the software and hardware required for the } \\
\text { experiment. }\end{array}$ \\
\hline $\begin{array}{l}\text { Primary experimental } \\
\text { stage }\end{array}$ & $\begin{array}{l}\text { In this stage, a first evaluation of the system } \\
\text { is made. }\end{array}$ \\
\hline $\begin{array}{l}\text { Secondary or subsequent } \\
\text { experimental stage }\end{array}$ & $\begin{array}{l}\text { During this stage, the data is collected } \\
\text { and improvements are made to the system. }\end{array}$ \\
\hline
\end{tabular}

Source: Based on (Fraser \& Gilbert, 1991)

As a first step to perform the experiment, the main user interfaces of the game were extracted, associated with the following tasks: Start the game, register the user, begin session, select a civilization (Figure 2), select bone for counting, erase bone markings, mark the bone again, enter number of fruits (Figure 3), validate answer and move on to the next problem.

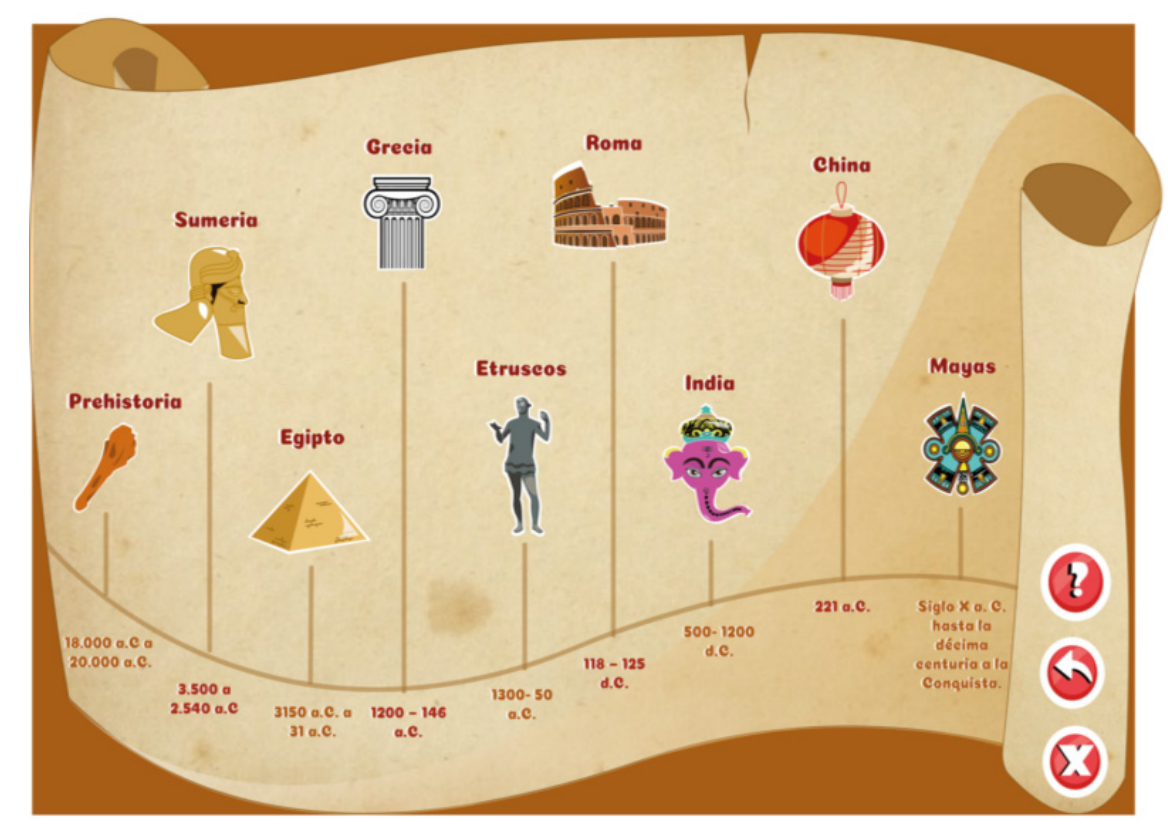

Figure 2. Interface of the task of selecting civilization 


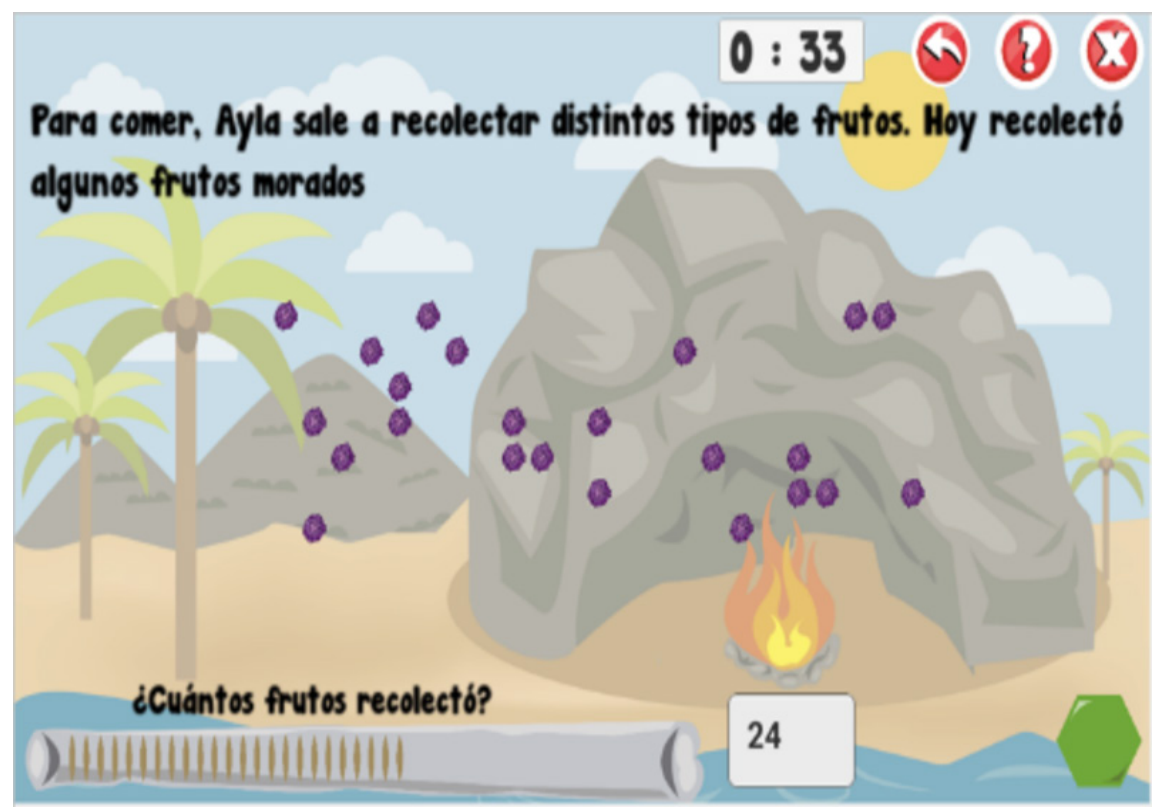

Figure 3. Interface of the tasks of marking the bone for counting, erasing bone marks, marking the bone again, entering number of fruits

The work was performed with 7 teachers between the ages of 34 and 64 who currently work with children with ADHD, either as learning facilitators or support teachers at Support Service for Regular Education Units (USAER, for the Spanish original). Information on the teachers was recorded, including their gender and age. The time it took to perform each task was measured, and the number of mistakes made during task performance was also recorded. Lastly, a CSUQ (Lewis, 1995) questionnaire was filled out to measure usability.

The next section describes the results of the evaluation and provides a discussion on the results.

\section{Results and discussion}

The results of the study are presented below, followed by a discussion based on each section's results.

\subsection{CSUQ questionnaire to evaluate the usability of the serious game}

A CSUQ (Lewis, 1995) questionnaire was used to measure the usability of the prehistoric civilization in the "UvaMate" game, in four (4) dimensions: usability of the system, quality of the information, quality of the interface and overall satisfaction.

The questionnaire was filled out by 7 teachers, who evaluated the 10 tasks listed below:

1. Begin game

2. Register user

3. Start session

4. Select civilization

5. Mark bone for counting

6. Erase marks on bone

7. Mark bone again

8. Enter number of fruits

9. Validate answer

10. Move on to next problem

Table 3 displays the results obtained from the CSUQ questionnaire. Based on the results and the comments made by the teachers, it was found that in terms of usability of the system, the teachers were 
satisfied with the ease of use. They believe it is simple to use, but some tasks, such as erasing the bone markings and moving on to the next problem, did not seem altogether clear to them. In general, they said that they felt comfortable and they believe it is easy to learn how to use it.

Table 3. CSUQ Results

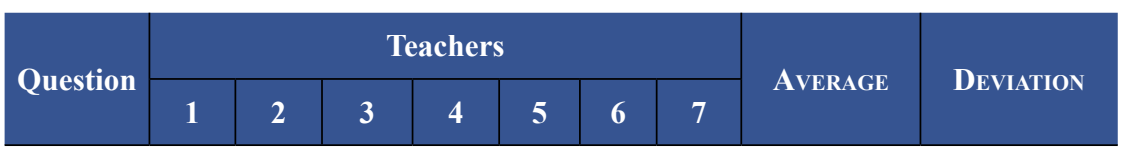

System usability

\begin{tabular}{c|c|c|c|c|c|c|c|c|c}
\hline 1 & 7 & 7 & 6 & 7 & 7 & 7 & 6 & 6.71428571 & 0.48795004 \\
\hline 2 & 7 & 7 & 6 & 7 & 7 & 7 & 7 & 6.85714286 & 0.37796447 \\
\hline & 7 & 7 & 5 & 7 & 7 & 7 & 7 & 6.71428571 & 0.75592895 \\
\hline 4 & 7 & 7 & 7 & 7 & 7 & 7 & 7 & 7 & 0 \\
\hline 5 & 7 & 7 & 6 & 7 & 7 & 6 & 7 & 6.71428571 & 0.48795004 \\
\hline 6 & 7 & 7 & 7 & 7 & 7 & 7 & 5 & 6.71428571 & 0.75592895 \\
\hline 7 & 7 & 7 & 6 & 7 & 7 & 6 & 7 & 6.71428571 & 0.48795004 \\
\hline 8 & 5 & 7 & 7 & 7 & 7 & 7 & 7 & 6.71428571 & 0.75592895 \\
\hline
\end{tabular}

Quality of the informati

\begin{tabular}{c|c|c|c|c|c|c|c|c|c}
\hline 9 & 6 & 5 & 7 & 7 & 7 & 7 & 7 & 6.57142857 & 0.78679579 \\
\hline 10 & 6 & 7 & 5 & 7 & 7 & 7 & 7 & 6.57142857 & 0.78679579 \\
\hline 11 & 7 & 6 & 7 & 7 & 7 & 7 & 7 & 6.85714286 & 0.37796447 \\
\hline 12 & 7 & 7 & 7 & 7 & 7 & 7 & 6 & 6.85714286 & 0.37796447 \\
\hline 13 & 7 & 7 & 7 & 7 & 7 & 7 & 7 & 7 & 0 \\
\hline 14 & 7 & 7 & 7 & 7 & 7 & 7 & 7 & 7 & 0 \\
\hline 15 & 7 & 7 & 7 & 7 & 7 & 7 & 7 & 7 & 0 \\
\hline
\end{tabular}

Quality of the interface

\begin{tabular}{c|c|c|c|c|c|c|c|c|c}
\hline 16 & 7 & 7 & 7 & 7 & 7 & 7 & 7 & 7 & 0 \\
\hline 17 & 7 & 7 & 7 & 7 & 7 & 7 & 7 & 7 & 0 \\
\hline 18 & 5 & 7 & 7 & 7 & 7 & 7 & 7 & 6.71428571 & 0.75592895 \\
\hline \\
Overall satisfaction \\
\hline 19 & 7 & 7 & 7 & 7 & 7 & 7 & 7 & 7 & 0 \\
\hline
\end{tabular}

In terms of the dimension of quality of the information, they said that the error messages are not clear and create confusion as to how to correct the errors. Certain details of buttons and typography need to be revised, but they believe it is easy to find the information and that the messages are clear.

Regarding the quality of the interface, they found it to be pleasant, though they would like it to have additional help functions to provide guidance in the case of doubts.

Lastly, all the teachers felt satisfied with the system and are enthusiastic about using it, not only with children with ADHD, but also with regular students.

Table 4 and Figure 4 display the maximum, minimum and average values for each dimension. Given that the maximum score in this evaluation is 7 , we may conclude that the game received a good evaluation by the teachers in terms of usability. 
Table 4. Usability Test CSUQ Questionnaire

\begin{tabular}{c|c|c|c} 
Dimension & Minimum & Maximum & Average \\
\hline System usability & 6.33632124 & 7.09225019 & 6.71428571 \\
\hline Quality of the information & 7 & 7 & 7 \\
\hline Quality of the interface & 6.33632124 & 7.09225019 & 6.71428571 \\
\hline Overall satisfaction & 7 & 7 & 7 \\
\hline
\end{tabular}

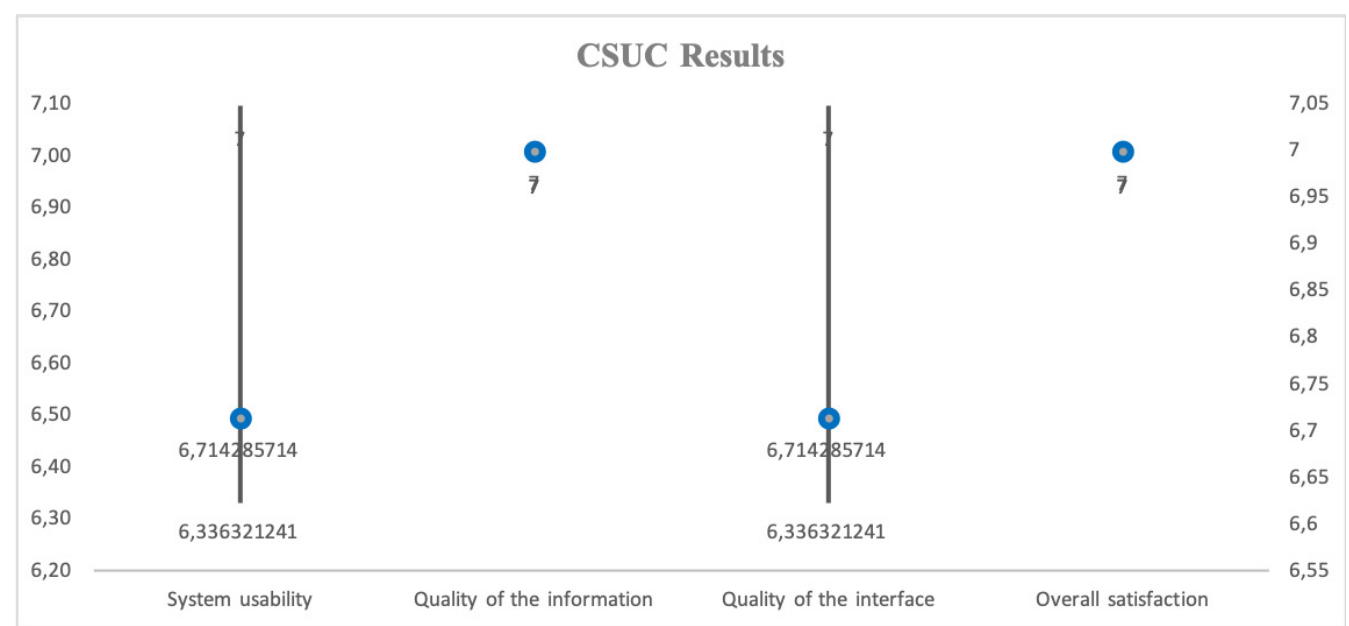

Figure 4. CSUQ Results

\subsection{Relationship between the personal aspects of users and interface usage}

As mentioned in the previous section, personal data on the users was gathered, such as age and gender, in order to assess whether these had any effect on the time of performance and understanding of the tasks.

Table 5 and Figure 5 display the average number of mistakes made by the teachers during performance of each task. These confirm the results found in the usability questionnaire regarding the activities of marking the bone for counting and erasing the marks from the bone, which create confusion during task performance.

Table 5. Average number of mistakes

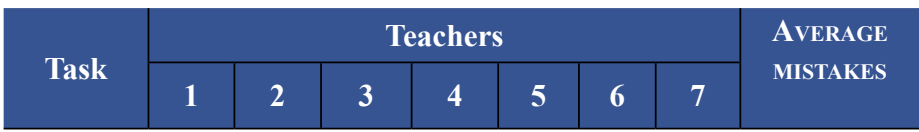

\begin{tabular}{c|c|c|c|c|c|c|c|c}
\multicolumn{2}{l}{ System usability } \\
\hline 1 & 0 & 0 & 0 & 0 & 0 & 0 & 0 & - \\
\hline 2 & 0 & 0 & 0 & 0 & 0 & 0 & 1 & 0.1429 \\
\hline 3 & 0 & 0 & 0 & 0 & 1 & 0 & 0 & 0.1429 \\
\hline 4 & 0 & 0 & 0 & 0 & 1 & 0 & 0 & 0.1429 \\
\hline 5 & 0 & 0 & 1 & 0 & 0 & 1 & 0 & 0.2857 \\
\hline 6 & 1 & 0 & 1 & 0 & 0 & 1 & 1 & 0.5714 \\
\hline 7 & 0 & 0 & 0 & 0 & 0 & 0 & 1 & 0.1429 \\
\hline 8 & 0 & 0 & 0 & 0 & 0 & 0 & 0 & - \\
\hline 9 & 1 & 0 & 0 & 0 & 0 & 0 & 0 & 0.1429 \\
\hline 10 & 1 & 0 & 0 & 0 & 0 & 0 & 0 & 0.1429 \\
\hline
\end{tabular}




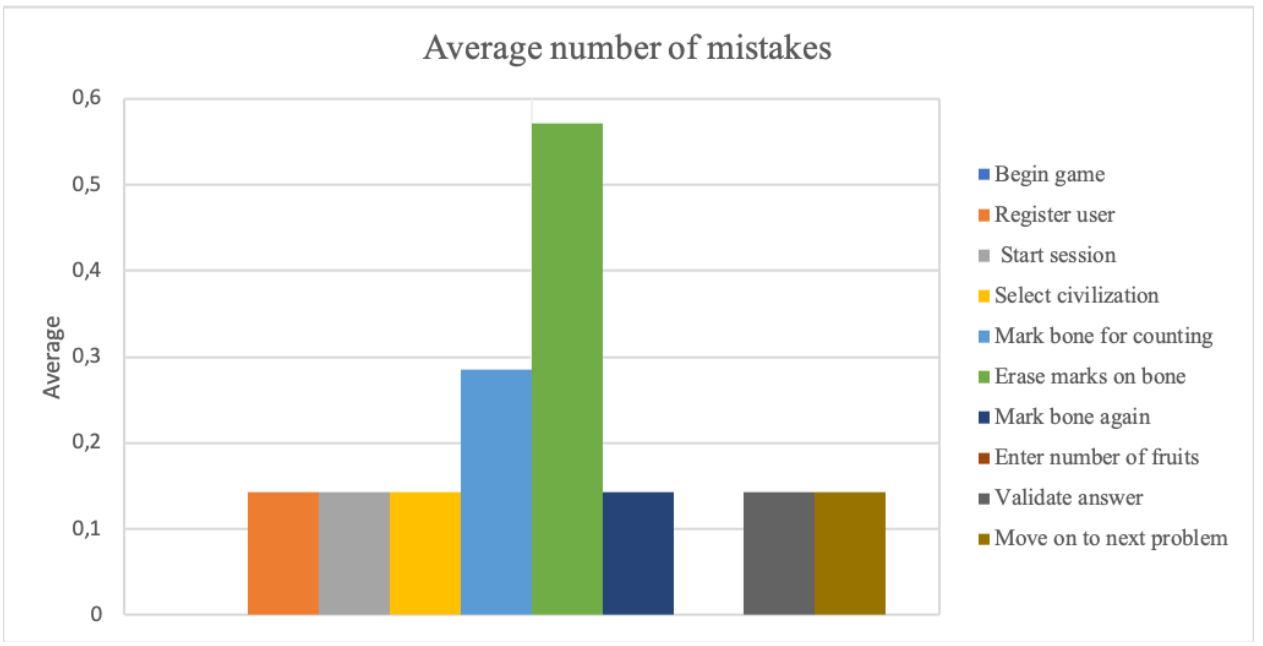

Figure 5. Average number of mistakes

Table 6 and Figure 6 indicate that there is no relationship between age and the time it took to perform the tasks. Some teachers were curious and they did not always follow the instructions, but instead followed their instincts to see what would happen if they performed a certain action, or asked questions on whether what they were doing was correct.

Table 6. Time of task performance and teacher age

\begin{tabular}{c|c|c} 
Question & Ages & Time of task \\
\hline Teacher 1 & 55 & $00: 06: 00$ \\
\hline Teacher 2 & 36 & $00: 01: 00$ \\
\hline Teacher 3 & 64 & $00: 05: 00$ \\
\hline Teacher 4 & 57 & $00: 07: 00$ \\
\hline Teacher 5 & 27 & $00: 02: 00$ \\
\hline Teacher 6 & 49 & $00: 04: 00$ \\
\hline Teacher 7 & 34 & $00: 18: 00$ \\
\hline Average & 46 & $00: 06: 09$ \\
\hline
\end{tabular}

Time of evaluation performance and teacher age

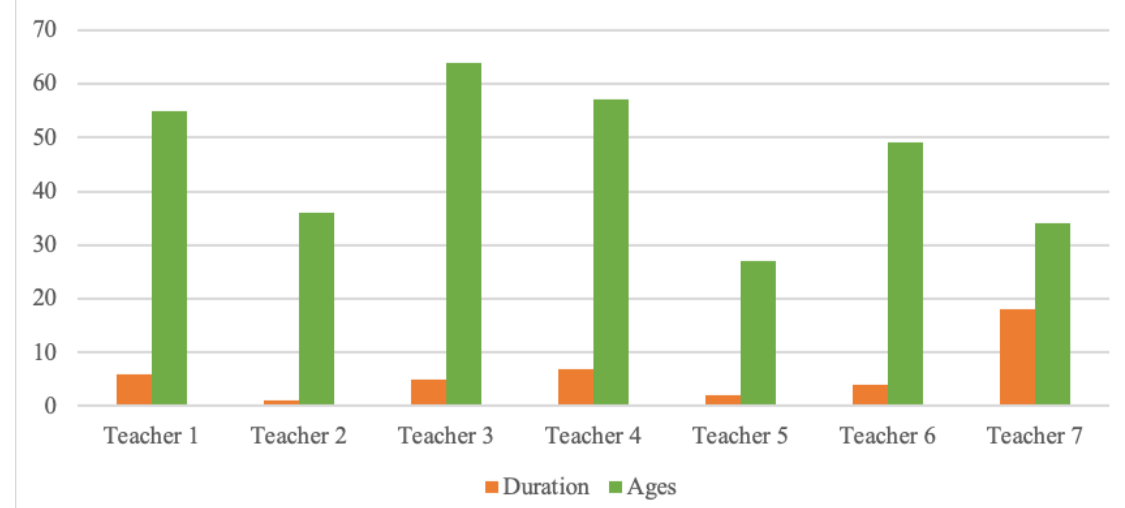

Figure 6. Time of evaluation performance and teacher age 


\subsection{User experience}

Figure 7 displays a graph of the results of the PrEmo questionnaire applied to the children to assess how they felt during activity performance. In the graph, scores between 1 and 5 were assigned to measure the level of satisfaction, where 5 is very satisfied and 1 is unsatisfied. The graph indicates that in general the children were satisfied with activity performance, and were even motivated about discovering new civilizations; however, the older children did not think it was particularly novel.

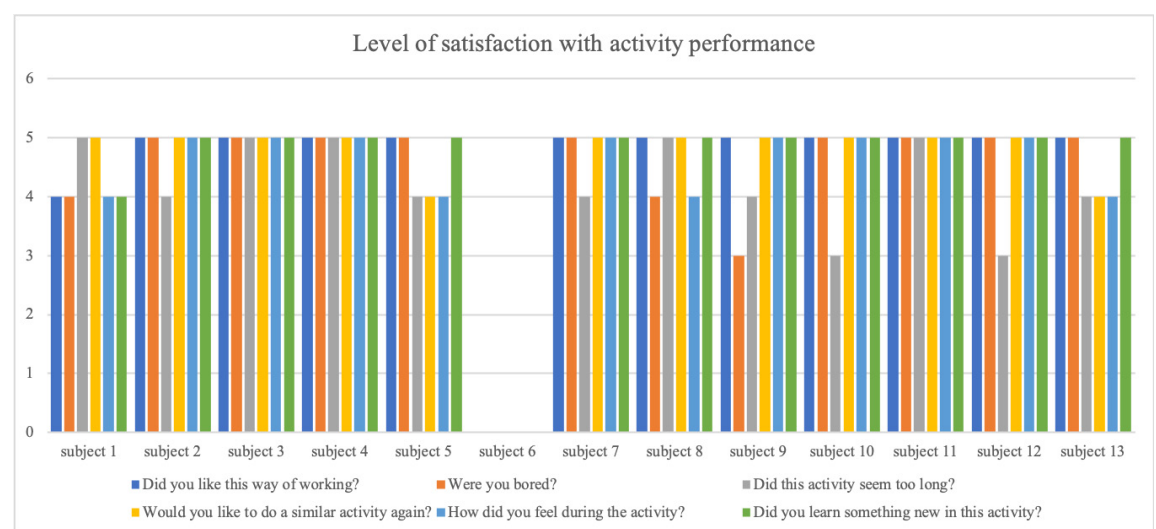

Figure 7. User experience of children with ADHD when carrying out the activity

Figure 8 and Table 7 display the time it took to perform the activity, which ranged between 7 and 18 minutes.

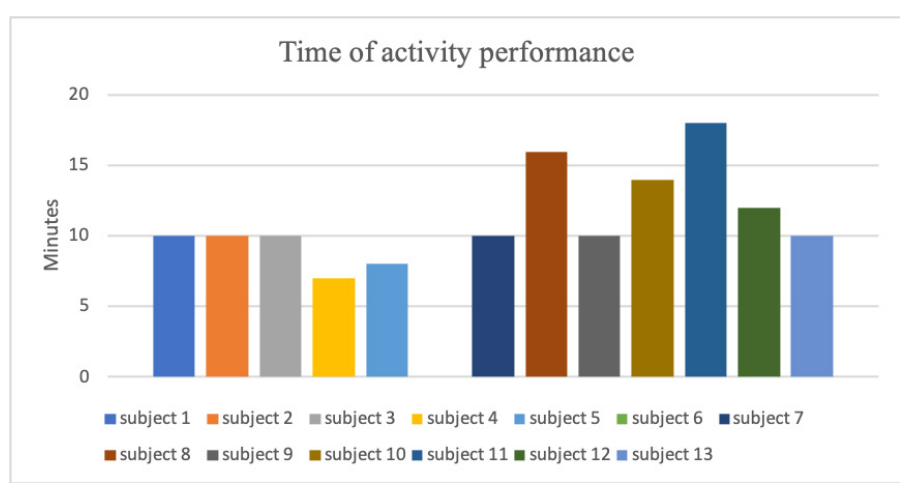

Figure 8. Time of activity performance by children

Table 7. Time of activity performance

\begin{tabular}{c|c} 
Student & Time of activity performance \\
\hline subject 1 & $0: 10: 00$ \\
\hline subject 2 & $0: 10: 00$ \\
\hline subject 3 & $0: 10: 00$ \\
\hline subject 4 & $0: 07: 00$ \\
\hline subject 5 & $0: 08: 00$ \\
\hline subject 6 & $0: 00: 00$ \\
\hline subject 7 & $0: 10: 00$ \\
\hline subject 8 & $0: 16: 00$ \\
\hline subject 9 & $0: 10: 00$ \\
\hline subject 10 & $0: 14: 00$ \\
\hline subject 11 & $0: 18: 00$ \\
\hline subject 12 & $0: 12: 00$ \\
\hline subject 13 & $0: 10: 00$ \\
\hline
\end{tabular}


Table 8 displays some of the field observations and notes describing the reactions of the children diagnosed with ADHD during activity performance, as described below.

Table 8. Observation of children solving problems of the first civilization

\section{Subject 1}

She thinks the narration made by Pythagoras is funny; she wants it to move faster and begins to click the mouse repeatedly. She is asked to pay attention, but it does not seem attractive to her and she continues to laugh. Afterwards, when she is supposed to listen to the story about the civilization, she does not want to and asks why she has to do all this just to play. She makes a bored face and begins to click on the mouse.

P.1. She clicks and counts at the same time. For a moment she loses focus and loses count, and asks whether she has to count everything. She counts 25 fruits and gets an error. She is asked to correct the result, and, as she laughs, says that we are mean. She once again gets a wrong answer and decides to count directly in the image, and finds the correct answer.

... 8 year-old girl in the 3 rd grade Subject 2

She says she does not like the type of letter font used in the game. She uses a good strategy for the count and quickly completes the activity. She said she liked the activity a lot, though she looked a bit nervous.

... 9-year old girl in the 4th grade

Subject 3

He forgot her glasses and she cannot see well. He moves constantly, especially his head, while he listens to the narration. He fluidly reads each one of the problems, and demonstrated that he had strategies to expedite the process, and was able to quickly and correctly complete the task. Reasoning skills were observed.

... 9-year-old boy in the 3rd grade

\section{Subject 4}

Listens attentively to the story, but moves constantly. While performing the tasks he is restless and he moves constantly.

During the count he used strategies to check that the result is correct.

\section{Subject 5}

...... 9-year-old boy in 3rd grade

He apparently pays attention to the story, but when the time came to solve the problems, he did not identify the numbers, and did not read the problems, and clicked randomly without knowing why or what for. Could not follow the number sequence to 29 , and skipped 23 . When he was explained how to check the result, he managed to find the correct answer. He is confused that when he counts mentally he gets a different result from the one shown on the screen using Ishango's bone.

... 9-year-old boy in the 3rd grade

The following section discusses the conclusions of the evaluation and future work.

\section{Conclusions and future work}

This paper presented an evaluation on the usability and user experience for one of the civilizations included in the "UvaMate" serious game, for the development of mathematical problem-solving skills for children with ADHD. The game was designed taking into consideration the special needs of this segment of the population.

The results are promising, as they display a high level of user satisfaction with the tested interface. Also, both the children and teachers have indicated that they are motivated and enthusiastic about using resources of this type. The teachers believe it is important to use new strategies to promote learning both for regular students and children diagnosed with this disorder, while the children display curiosity and excitement about working and experimenting with a new way of learning through tools of this type. 
It is important to make the changes requested by the teachers in terms of interfaces and contents. It is also important to take into consideration all the comments made by the children, because they are the target users for whom the game has been designed.

Future work will include working on the development of the next civilizations, taking into consideration the results and observations made during the evaluation.

\section{Acknowledgments}

We wish to thank the Council of Science and Technology (CONACYT, for the Spanish original) for its support and sponsorship of the Doctoral Research project, as part of the Educational Systems and Environment Doctorate program of Benemérita Universidad Autonoma de Puebla. We also thank all the teachers who voluntarily participated in our research project.

\section{Statement of conflicts of interest}

The authors declared no potential conflicts of interest with respect to the research, authorship and/or publication of this article.

\section{References}

Alvárez Menéndez, S., \& Pinel González, A. (2015). Trastorno por déficit de atención con hiperactividad en mi aula de infantil//Attention deficit hyperactivity disorder in my preschool classroom. REOP - Revista Española de Orientación y Psicopedagogía, 26(3), 141-152. https://doi.org/10.5944/reop.vol.26.num.3.2015.16406

American Psychiatric Association. (2000). Diagnostic and Statistical Manual of Mental Disorders-IV-TR (revised). Washington, DC: American Psychiatric Association Press.

Artigas-Pallarés, J., \& Narbona García, J. (2011). Trastornos del neurodesarrollo. Viguera editores.

Barkley, R. A., \& Murphy, K. R. (2006). Attention-deficit hyperactivity disorder: A clinical workbook (3rd editio). Guilford Press.

Bul, K. C. M., Franken, I. H. A., Van der Oord, S., Kato, P. M., Danckaerts, M., Vreeke, L. J., ... Maras, A. (2015). Development and User Satisfaction of "Plan-It Commander," a Serious Game for Children with ADHD. Games for Health Journal, 4(6), 502-512. https://doi.org/10.1089/g4h.2015.0021

Dow, S., Lee, J., Oezbek, C., MacIntyre, B., Bolter, J. D., \& Gandy, M. (2005). Wizard of Oz interfaces for mixed reality applications. En CHI '05 extended abstracts on Human factors in computing systems - CHI '05 (pp. 1339-1342). New York, New York, USA: ACM Press. https://doi.org/10.1145/1056808.1056911

Echeverry Chaves, N., \& González Valencia, S. A. (2014). Diseño de un videojuego didáctico de educación cívica para niños autistas, TDAH y discapacidad cognitiva. Teoría y Praxis Investigativa, 9(2), 116-127.

Fernández Martín, F. D., Hinojo Lucena, F. J., \& Aznar Díaz, I. (2003). Dificultades del alumnado con déficit de atención con hiperactividad (TDAH) en el aula: implicaciones para la formación docente. Enseñanza: anuario interuniversitario de didáctica, 21, 219-232.

Ford, M. J., Poe, V., \& Cox, J. (1993). Attending behaviors of ADHD children in math and reading using various types of software. Journal of Computing in Childhood Education, 4(2), 183-196.

Fraser, N. M., \& Gilbert, G. N. (1991). Simulating speech systems. Computer Speech \& Language, 5(1), 81-99. https://doi.org/10.1016/0885-2308(91)90019-M

Geary, D. C. (2004). Mathematics and Learning Disabilities. Journal of Learning Disabilities, 37(1), 4-15. https:// doi.org/10.1177/00222194040370010201

Higgins, S. (2000). The logical zoombinis. Teaching thinking, 1(1), 12-15.

Jenkins, H. (2002). Game theory: Digital renaissance. Technology Review, 1-3.

Keller, S. M. (1992). Children and the Nintendo.

Klimenko, O. (2009). Las dificultades en la autorregulación asociadas al TDAH y los aportes de la teoría históricocultural para su abordaje intracurricular. Revista Iberoamericana de Educación, 49(8), 1-10. 
Lau, H. M., Smit, J. H., Fleming, T. M., \& Riper, H. (2017). Serious Games for Mental Health: Are They Accessible, Feasible, and Effective? A Systematic Review and Meta-analysis. Frontiers in Psychiatry, 7. https://doi. org/10.3389/fpsyt.2016.00209

Lewis, J. R. (1995). IBM computer usability satisfaction questionnaires: Psychometric evaluation and instructions for use. International Journal of Human-Computer Interaction, 7(1), 57-78. https://doi. org/10.1080/10447319509526110

Londoño Palacio, O. L., Maldonado Granados, L. F., \& Calderón Villafáñez, L. C. (2014). Guías para construir estados del arte. Bogotá D.C.

Mahmoudi, H., Koushafar, M., Saribagloo, J. A., \& Pashavi, G. (2015). The Effect of Computer Games on Speed, Attention and Consistency of Learning Mathematics among Students. Procedia-Social and Behavioral Sciences, 176, 419-424. https://doi.org/10.1016/j.sbspro.2015.01.491

McFarlane, A., Sparrowhawk, A., \& Heald, Y. (2002). Report on the educational use of games. Cambridge: TEEM (Teachers evaluating educational multimedia).

Miranda, A., Jarque, S., \& Tarraga, R. (2006). Interventions in School Settings for Students With ADHD. Exceptionality, 14(1), 35-52. https://doi.org/10.1207/s15327035ex1401_4

Miranda Casas, A., Soriano Ferrer, M., \& García Castellar, R. (2002). Optimización del proceso de enseñanza/ aprendizaje en estudiantes con trastorno por déficit de atención con hiperactividad (TDAH). EduPsykhé: Revista de psicología y psicopedagogía, 1(2), 249-274.

Munoz, H. T., Navarro, S. B., \& Fabregat, R. (2014). Gremlings in My Mirror: An Inclusive AR-Enriched Videogame for Logical Math Skills Learning. En 2014 IEEE 14th International Conference on Advanced Learning Technologies (pp. 576-578). IEEE. https://doi.org/10.1109/ICALT.2014.168

Nur, N., \& Kavakci, O. (2010). Elementary school teachers' knowledge and attitudes related to attention deficit hyperactivity disorder. HealthMED, 4(2), 350-355.

Palacios-Cruz, L., de la Peña, F., Valderrama, A., Patiño, R., Calle Portugal, S. P., \& Ulloa, R. E. (2011). Conocimientos, creencias y actitudes en padres mexicanos acerca del trastorno por déficit de atención con hiperactividad (TDAH). Salud mental, 34(2), 149-155.

Rieber, L. P. (1996). Seriously considering play: Designing interactive learning environments based on the blending of microworlds, simulations, and games. Educational Technology Research and Development, 44(2), 43-58. https://doi.org/10.1007/BF02300540

Rief, S. F. (2012). How to reach and teach children with ADD/ADHD: Practical techniques, strategies, and interventions (Second Edi). John Wiley \& Sons, Inc.

Stephen, E. (2005). Highlights of the Attention Deficit Hyperactivity Disorder (ADHD). News Media Briefing. Medscape Psychiatry and Mental Health.

Wallace, N. (2005). The Perceptions of Mothers of Sons with ADHD. Australian and New Zealand Journal of Family Therapy, 26(4), 193-199. https://doi.org/10.1002/j.1467-8438.2005.tb00674.x

Whitebread, D. (1997). Developing children's problem-solving: the educational uses of adventure games. $E n$ Information technology and authentic learning (pp. 13-37). London: Routledge.

Wouters, P., van Nimwegen, C., van Oostendorp, H., \& van der Spek, E. D. (2013). A meta-analysis of the cognitive and motivational effects of serious games. Journal of Educational Psychology, 105(2), 249-265. https:// doi.org/10.1037/a0031311

Zimmerman, B. J., \& Schunk, D. H. (2001). Self-regulated learning and academic achievement: Theoretical perspectives (Second Edi). Routledge.

\section{About the authors}

\section{Claudia Blanca González Calleros}

Doctoral Student in the Educational Systems and Environments program at the Electronics Faculty of Benemérita Universidad Autónoma de Puebla. Professional in Civil Engineering. Is currently working on an Instruction Design Model for learning how to solve mathematical problems using technological tools such as serious games. 


\section{Josefina Guerrero García}

$\mathrm{PhD}$ from Université Catholique de Louvain (Belgium) with specialization in Human-Computer Interaction. Member of the consolidated academic body of Education Systems and Environments BUAP-CA-320, member of the National System of Researchers, Level I. Research professor of the Computer Sciences Faculty, of the Doctorate in Educational Systems and Environments and of the Doctorate in Engineering of Language and Knowledge, at Universidad Autónoma de Puebla. Her research interests include distance learning models, learning management, learning object development, user interface development for collaborative environments, development of learning applications for children with disabilities.

\section{Yadira Navarro Rangel}

Doctor in Education (UAA), Master's in Education Quality and Professional in Economics (UDLAP). Specialist in Public Policies on Modernization of Education. Research professor of the doctoral program in Educational Systems and Environments (DSAE-BUAP). Member of the National System of Researchers, Level 1. 